\title{
Impact of Educational Program for Deaf Students regarding Knowledge on malnutrition in Khartoum State
}

Nayf khaled Altoani MS ${ }^{1 *}$, Dr. Sara Lavinia Brair ${ }^{2}$

${ }^{\mathrm{T}}$ Department of Community Health Nursing, Faculty of Nursing, Al Neelain University

${ }^{2}$ Community Medicine Department, Faculty of Medicine, Al Neelain University

Article History

Received: 25.02 .2020

Accepted: 28.03 .2020

Published: 26.10 .2020

Journal homepage:

https://www.easpublisher.com/easjnm

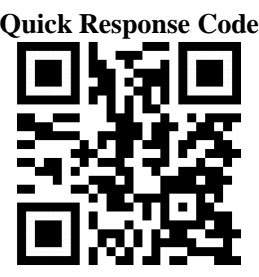

Abstract: Background: Malnutrition is directly responsible for 300,000 deaths per year in children younger than 5 years in developing countries and contributes indirectly to more than half of all deaths in children worldwide. In addition, it increases health care costs [1]. Nutritional education one of the important aspects that play a big role in nutritional knowledge by raising awareness and ultimately the health of the society [2]. Many adult deaf since birth or early child childhood have poor knowledge of healthy eating has adversely affected deaf people's nutritional health results from limited access to information that is considered common knowledge among hearing persons. For example, never overheard parents discussing about healthy eating [3]. Method: This study was conducted to determine changes in malnutrition knowledge for deaf students in classes 6and 7 after receiving a nutrition education program. (144) Deaf students studying at Al Amal schools were included in the study. The students were divided into two groups; an intervention group comprised of 72 students and control group that comprised of another 72 students. The program was conducted for 6 weeks which comprised of two parts; lectures, practical session (computer training) and a quiz at the end of the program. Questionnaires to assess Knowledge of deaf students were distributed to students before the intervention program, and after intervention. Data was analysed using statistical analysis program (SPSS). Ethical approval was obtained from Al Neelain IRB and permission from Al Amal schools. Informed consent was obtained from parents of the deaf student $s$ and assent from the students themselves. Results: Results show significant differences in experimental group between pretest where the mean value located in the fair range according to the tripartite Likert test of $1.67-2.33$, and posttest where majority of students' responses in the range between 2.34 - 3 and indicate to good knowledge. Results show also no significant differences in control group between pretest and posttest where the means value located in the fair range according to the tripartite Likert test of $1.67-2.33$. Conclusion and recommendation: The study concluded that the education program has a positive impact on the knowledge of deaf students regarding to malnutrition in Khartoum state, and we recommend replication of a similar studies in other topics and districts in Sudan especially in Al Amal schools.

Keywords: Malnutrition, deaf Students, and health education.

Copyright ( $\odot$ 2020 The Author(s): This is an open-access article distributed under the terms of the Creative Commons Attribution 4.0 International License (CC BY-NC 4.0) which permits unrestricted use, distribution, and reproduction in any medium for non-commercial use provided the original author and source are credited.

\section{INTRODUCTION}

Malnutrition is a common problem worldwide, and in developing countries it is associated particularly with poverty [4].

In 2015, more than half of all stunted children under 5 lived in Asia and more than one third lived in Africa, almost half of all overweight children under 5 lived in Asia and one quarter lived in Africa, and more than two thirds of all wasted children under 5 lived in Asia and more than one quarter lived in Africa. Malnutrition manifests itself in many different ways: as poor child growth and development. Malnutrition and diet are by far the biggest risk factors for the global burden of disease: every country is facing a serious public health challenge from malnutrition. The economic consequences represent losses of 11 percent of gross domestic product (GDP) every year in Africa and Asia, whereas preventing malnutrition delivers \$16 in returns on investment for every $\$ 1$ spent[5].

The causes of malnutrition are complex, ranging from biological and social to environmental factors. The causes of malnutrition can be classified as immediate (inadequate dietary intake, poor health), underlying (inadequate access to food, inadequate care for children and women, unhealthy environment, inadequate education) and basic (resources and control human, economic and organizational resources)[6]. 
As the relationships among diet, health, and disease prevention have become clearer, nutrition education and the promotion of healthy eating behaviours and lifestyles continue to receive increased attention. In its broadest sense, Education of the population about food processing and consumption may be very important in ensuring the best use of the available food [7].

Many adults' deaf since birth or early childhood have low health literacy. This low health literacy resulted from a lifetime of limited access to information that is often considered common knowledge among hearing persons [8].

Children with various disabilities are taught to use computers in their daily activities such as education, work, home appliances' control (turning lights, radio, TV...), communication and entertainment [9].

This study aimed to answer the following questions. Is there an impact of educational program for deaf students regarding knowledge on malnutrition in Khartoum State?

\section{METHODOLOGY}

This intervention quasi experimental facility based study conducted to determine changes in malnutrition knowledge for deaf students in classes 6 and 7 after receiving a nutrition education program in Khartoum State. The study included 144 students that were divided equally into two groups, 72 students for the intervention group and 72 students for the control group from $\mathrm{Al}$ Aaml schools in Omdurman and Khartoum three participated in study. The experimental group in the schools received nutrition education program over a period of 6 weeks, while the control group did not receive program. The educational program consisted in two parts; lectures and practical sessions. The program started with the lectures first, two lectures were presented to the student; every lecture was about one hour long, one lectures pre week. The practical part consisted of computer training which was presented mainly principles of computer use for all members in experimental group in two hours after that each student opened computer and use cd-room with one of the research teams. After that Electronic application included (text, pictures, questions, and answers and feedback about malnutrition) distributed to every student in experimental groups and let students used it for three weeks before final data collection. The questionnaire to assess deaf students Knowledge was distributed before and after intervention program. Data were analyzed using SPSS (Statistical Package for Social Sciences). Results of the Chi test for the responses of the sample show a significant statistical differences ( $\mathrm{p}$-value 0.000), among experimental group (pre and post) educational program. Results also show no significant statistical differences ( $p$-value 0.000), among control group (pre and post) educational program. Ethical approval was obtained from Al Neelain (I R B), the parents of the students were asked to sign the informed consent form after the purpose of the study had been explained to them, and the anonymity and confidentiality of responses, voluntary participation and right to withdrawal from study were emphasized. Assent of the students also taken in within form.

\section{RESULTS}

The tripartite Likert test to identify Knowledge level by weighed mean average was as follows:

\begin{tabular}{|l|l|}
\hline Levels & Mean weight average \\
\hline low & $1-1.66$ \\
\hline Fair & $1.67-2.33$ \\
\hline Good & $2.34-3$ \\
\hline
\end{tabular}

\section{Demographic data tables:}

Table-1

\begin{tabular}{|r|l|r|r|r|r|}
\hline \multicolumn{7}{|c|}{ Schools } \\
\hline \multirow{3}{*}{ Valid } & AL-Amal Khartoum & 60 & Percent & Valid Percent & Cumulative Percent \\
\cline { 2 - 6 } & AL-Amal Omdurman & 84 & 41.7 & 41.7 & 41.7 \\
\cline { 2 - 6 } & Total & 144 & 100.0 & 58.3 & 100.0 \\
\hline
\end{tabular}

school

(144) deaf students form Al Amal schools, (60) students from Khartoum three school, (44) from Omdurman

Table-2

\begin{tabular}{|c|c|c|c|c|c|}
\hline \multicolumn{6}{|c|}{ Class } \\
\hline & & $\mathbf{N}$ & Percent & Valid Percent & Cumulative Percent \\
\hline \multirow[t]{3}{*}{ Valid } & 7 th & 76 & 52.8 & 52.8 & 52.8 \\
\hline & 8 th & 68 & 47.2 & 47.2 & 100.0 \\
\hline & Total & 144 & 100.0 & 100.0 & \\
\hline
\end{tabular}

The majority of students (59\%) were males, and (41\%) were females. 
Table-3

\begin{tabular}{|r|l|r|r|r|r|}
\hline \multicolumn{2}{|c|}{} & \multicolumn{1}{|c|}{ N } & Percent & Valid Percent & Cumulative Percent \\
\hline \multirow{3}{*}{ Valid } & Male & 85 & 59.0 & 59.0 & 59.0 \\
\cline { 2 - 6 } & Female & 59 & 41.0 & 41.0 & 100.0 \\
\cline { 2 - 6 } & Total & 144 & 100.0 & 100.0 & \\
\hline
\end{tabular}

In this study, $(52,8 \%)$ students were in 6 th class and $(47,2 \%)$ in 7 th.

Table-4: Experimental group knowledge regarding to malnutrition

\begin{tabular}{|l|l|c|c|c|c|c|c|l|l|}
\hline Test & $\mathbf{N}$ & Frequency & Incorrect & Don't know & Correct & Mean & Deviation & Chi & P \\
\hline Pre & 72 & 288 & $54.51 \%$ & $12,84 \%$ & $32.63 \%$ & 1.80 & 0.93 & 454.321 & 0.000 \\
\hline post & 72 & 288 & $27.08 \%$ & $14,93 \%$ & $57.89 \%$ & 2.61 & 0.88 & 454.321 & 0.000 \\
\hline
\end{tabular}

Table (4) show the Chi test in the pretest was 454.321 with a mean of 1.86 with a standard deviation of 0.93 . The value of the Chi test in the post-test was 454.321 with a mean of 2.66 with a standard deviation of 0.88 .

We conclude from the above that there are significant a difference in the pretest group where the mean value is 1,80 and it is located in the fair range according to the tripartite Likert test of $1.67-2.33$.

The majority of respondents' responses to the post-test was 2.61 in the range between 2.34 - 3 and indicates good knowledge.

Table-5: Paired Differences of the knowledge of deaf students in experimental group regarding to malnutrition

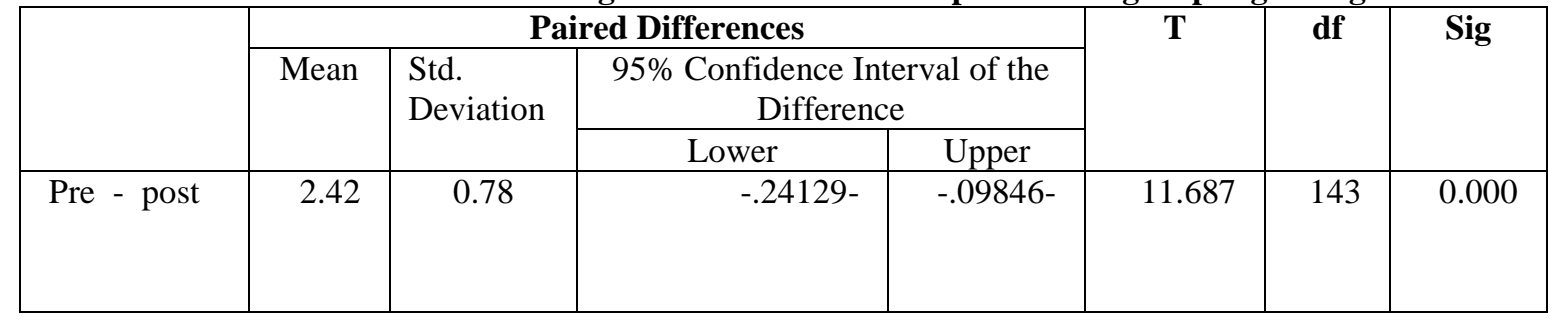

Table (5) show significant statistical differences (p-value 0.000), among experimental group (pre and post) educational program

Table-6: control group knowledge regarding to malnutrition

\begin{tabular}{|l|l|l|l|l|l|l|l|l|l|}
\hline Test & $\mathbf{n}$ & Frequency & Incorrect & Don't know & Correct & Mean & Deviation & Chi & p \\
\hline Pre & 72 & 1872 & $52.43 \%$ & $13.54 \%$ & $34,03 \%$ & 1.81 & 0.93 & 411.433 & 0.000 \\
\hline post & 72 & 1872 & $53.81 \%$ & $12.15 \%$ & $34.04 \%$ & 1.77 & 0.93 & 407.249 & 0.000 \\
\hline
\end{tabular}

Table (6) show the Chi test in the pretest was 411.433 with a mean of. 1.82 with a standard deviation of 0.93 . The value of the Chi test in the post-test was 407.249 with a mean of 1.84 with a standard deviation of 0,93 .

We conclude from the above that there are significant differences in the pretest group indicating where the mean value is 1,82 and it is located in the fair range according to the tripartite Likert test of 1.67 2.33 .

The majority of responses to the post-test were 1.84 in the range between $1.67-2.33$ and indicate fair knowledge too.

Table-7: Paired Differences of the knowledge of deaf students in control group regarding to malnutrition.

\begin{tabular}{|c|c|c|c|c|c|c|c|}
\hline & \multicolumn{4}{|c|}{ Paired Differences } & \multirow[t]{3}{*}{$\mathbf{T}$} & \multirow[t]{3}{*}{ df } & \multirow[t]{3}{*}{ Sig } \\
\hline & \multirow[t]{2}{*}{ Mean } & \multirow[t]{2}{*}{$\begin{array}{l}\text { Std. } \\
\text { Deviation }\end{array}$} & \multicolumn{2}{|c|}{$\begin{array}{l}95 \% \text { Confidence Interval } \\
\text { of the Difference }\end{array}$} & & & \\
\hline & & & Lower & Upper & & & \\
\hline Pre - post & 1.73 & 0.93 & $-.004-$ & $-.01-$ & 4.131 & 143 & 0.000 \\
\hline
\end{tabular}


Table (7) show no significant statistical differences (p-value 0.000), among control group (pre and post) educational program

\section{DISCUSSION}

This study conducted to identify impact of educational program for deaf students regarding knowledge to malnutrition in Khartoum State. Malnutrition knowledge of deaf students was test with 6 questions. Results show significant statistical differences among study experimental groups (pre and post) education program. Are significant differences in the posttest group indicating fair knowledge where the mean value is 1,86 and it is located in the fair range according to the tripartite Likert test of $1.67-2.33$. The majority of respondents' responses to the post-test was 2.66 in the range between $2.34-3$ and indicates good knowledge. The result also shows majority of the responses of the control group pre and post tests were in the extent of the fair knowledge according to the test of the triple Likert from 0 - 1.66. Data showed there was significant improvement in students' nutrition knowledge before and after attending educational program form fair to good in experimental group. When compared to similar study [9] conducted in Egypt to improve the nutrition awareness and nutritional status of students with hearing impairment. Which showed significant improvement in information (improving the degree of nutritional information from (19.74) before the program to $(39,17)$ after program, as well as improving the degree of dietary behaviour and habits from $(27$ to 29,5$)$ degree to $(34,12$ to 35,48$)$ degree before and after the program respectively. Another study [10] in Lebanon to evaluated the impact of a 6month school nutrition intervention on changes in dietary knowledge, attitude, behavior (KAB) and nutritional status of Syrian refugee children. That fined significant increases in dietary knowledge in experimental group. According to the result of the study and other studies positive impact of health education program is clear, but this effect varies according to the circumstances (place, sample characteristics, tools) surrounding each study. Study has shown that a wellexecuted education program could improve students' knowledge towards malnutrition. In addition, the usage of educational technology such as CD in this program may attract children's attention to learn and understand better. This program could be adapted by other schools for deaf students in Sudan. By implementing the program in schools, it will give a positive impact by inculcating good nutrition knowledge in deaf students, and that hopefully will persist throughout their lives. It is recommended Replication of similar studies in other topics and districts in Sudan especially in Al Amal schools.

\section{REFERENCES}

1. Liu, H., Xu, X., Liu, D., Rao, Y., Reis, C., Sharma, M., \& Zhao, Y. (2018). Nutrition-related knowledge, attitudes, and practices (KAP) among kindergarten teachers in Chongqing, China: A cross-sectional survey. International journal of environmental research and public health, 15(4), 615.

2. Contento, I. R. (2011). Nutrition Education: Linking Research, Theory, and Practice (2nd edition). Sudbury, MA: Jones and Bartlett Publishers.

3. Barnett, S., McKee, M., Smith, S. R., \& Pearson, T. A. Deaf Sign Language Users, Health Inequities, and Public Health: Opportunity for Social Justice Posted on February 15, 2011 by.

4. Lupton, J. R., Brooks, J. A., Butte, N. F., Caballero, B., Flatt, J. P., \& Fried, S. K. (2002). Dietary reference intakes for energy, carbohydrate, fiber, fat, fatty acids, cholesterol, protein, and amino acids. National Academy Press: Washington, DC, USA, 5, 589-768.

5. Best, C. (Ed.). (2008). Nutrition: a handbook for nurses (Vol. 22). John Wiley \& Sons.

6. Ashworth, A., Chopra, M., McCoy, D., Sanders, D., Jackson, D., Karaolis, N., \& Schofield, C. (2004). WHO guidelines for management of severe malnutrition in rural South African hospitals: effect on case fatality and the influence of operational factors. The Lancet, 363(9415), 1110-1115.

7. Contento, I.R. (2011). Nutrition Education: Linking Research, Theory, and Practice (2nd edition). Sudbury, MA: Jones and Bartlett Publishers.

8. University of Waikato. (2002). Greenstone Digital Library Software. Retrieved February 11, 2003, from http://www.greenstone.org/english/home.html.

9. Abeer, Mustafa, A.K. (2017). Effect of Nutrition Education on hearing handicapped students in preparatory stage. Thesis (Ph.D.) Aeen shames University. Faculty of Education.

10. Harake, E., Diab, M., Kharroubi, S., Hamadeh, S. K., \& Jomaa, L. (2018). Impact of a pilot schoolbased nutrition intervention on dietary knowledge, attitudes, behavior and nutritional status of syrian refugee children in the Bekaa, Lebanon. Nutrients, 10(7), 913. 